\title{
Exploring the Relationship of Enrollment in IDR to Borrower Demographics and Financial Outcomes
}

\author{
Daniel A. Collier \\ W. E. Upjohn Institute for Employment Research
}

\section{Dan Fitzpatrick}

\author{
Christopher R. Marsicano \\ Davidson College
}

Author Note: Dr. Daniel A. Collier is a Research Associate at the W. E. Upjohn Institute for Employment Research. Dr. Dan Fitzpatrick is an independent education policy analyst and researcher; he conducted the majority of the data management for this manuscript. Christopher R. Marsicano is a Visiting Assistant Professor of Educational Studies at Davidson College. Written correspondence concerning this research brief should be addressed to Daniel A. Collier, Ph.D., W. E. Upjohn Institute for Employment Research, 300 S. Westnedge Avenue, Kalamazoo, MI 49007-4686. This manuscript is a working draft and should not be cited without permission. 


\begin{abstract}
The Senate HELP committee is considering changes to income-driven repayment (IDR) schemes for student loans, necessitating research that examines the characteristics and financial behaviors of the borrowers in IDR programs. Using descriptive methods and a nationally representative sample, we examine the demographics of IDR enrollment. Contrary to the intention of the policy, we find that low-income borrowers and borrowers with high debt-to-income ratios are less likely to enroll in IDR. We also find that married women of color are likely to enroll in IDR programs as are borrowers with more than $\$ 50 \mathrm{~K}$ in student loan debt. Finally, we find that enrollment in IDR does not predict engagement in other financial behaviors such as saving for retirement or buying real estate. The paper ends with a discussion of the implications of these findings for federal financial aid policy.
\end{abstract}

Keywords: Income-driven repayment, student debt, loans

JEL Codes: I22, I23, I24 
Exploring the Relationship of Enrollment in IDR to

Borrower Demographics and Financial Outcomes

Until recently, policymakers have generally opposed economists' recommendations to link student loan repayment to income (e.g. Friedman, 1955), citing the complexity that an income-driven repayment (IDR) scheme would introduce to repayment and the concentration of IDR benefits among lower-earners (Shireman, 2017). Although mortgage-like repayment plans have been the norm for decades, policymakers have recently opened access to IDR programs. IDR is an increasingly popular repayment scheme for millions of borrowers (U.S. Government Accountability Office, 2016). Despite increasing IDR enrollment, we know very little about who enrolls in IDR and how enrollment in IDR relates to financial outcomes like homeownership.

Rational choice would suggest that those with high student loan debt and low incomes or other financial priorities would enroll in IDR, but limited publicly-available national datasets limit exploration of loan repayment behavior on an individual level (Hillman \& Bruecker, 2018). Recently, Collier (2019) examined a non-nationally-representative sample of borrowers, finding some elements of this rational choice as total student loan debt (over $\$ 60,000)$ and wages $(\$ 25,000-54,999)$ were significant correlates to IDR enrollment. Demographically, women were also positively linked with IDR enrollment - supporting beliefs that despite several well-known systemic disadvantages (like the wage gap), women find financial safety in IDR (Miller, 2017).

\section{Problem Statement and Key Findings}

Policymakers have expressed interest in modifying IDR programs, but possess a limited understanding of current IDR enrollment or results. We use the Survey of Consumer Finances (SCF) database to test Collier's (2019) prior findings and bolster a general understanding of who 
has enrolled in IDR. The SCF database is a publicly available nationally representative database that matches individual profiles to enrollment in an IDR program, allowing us to ask:

1. How do demographics, loan debt, and wages correlate with enrollment in IDR?

2. Does IDR enrollment relate to financial outcomes such as savings and home ownership?

\section{Key Findings}

Using OLS regression, we find that income does not show a pattern of driving enrollment in IDR. In contrast, across all models examined, women were more likely to enroll in IDR than men. For all other characteristics, the relationships that stand out (as statistically significant and of an important magnitude) are contingent on what measurements are included in a model. Debt shows no relationship with IDR enrollment when considered as a continuous measure or as several categories (Table 1); but those with high debt $(>\$ 50 \mathrm{~K}$, following Looney \& Yannelis, 2018) are more likely to enroll (Table 2). Whether racial minority status appears to correlate with increased IDR participation depends on the model examined. Educational attainment categories do not relate to IDR status; but those with some college or an associate's degree are more likely than any other group to participate. We think it is crucial for other analysts to realize that findings around IDR participation may be highly sensitive to how groups are defined and what covariates are in models. Finally, when controlling for demographic factors, debt, and wages, enrollment in IDR was not correlated with savings, retirement, or home ownership (Table 3).

\section{Prior Literature}

The limited available research suggests IDR schemes consist of a higher percentage of low-to-moderate earners (Blagg, 2018), despite prior assertions that higher earners may abuse IDR-related tax benefits and the promise of loan forgiveness in ways Congress did not intend (Delisle, 2013). IDR exists to ease financial strain for those with higher debt loads who cannot 
afford traditional repayment, which seems to hold true across several descriptive studies (Blagg, 2018; Frotman \& Gibbs, 2017). So too does the contention that IDR subsidizes many borrowers with graduate and professional degrees (Brooks, 2018). Collier's (2019) recent study supports assertions that graduate (and maybe professional) degrees are positively correlated with IDR enrollment. However, high student loan debt balances and being a middle-earner showed stronger links with enrollment.

We know even less about which demographic factors correlate to enrollment in IDR. Some have theorized that because female (Becker, 2017) and minority (Scott-Clayton \& Li, 2016) borrowers possess higher debt loads, that IDR may be critically important to these individuals (Miller, 2017). Furthermore, mothers of color are much more likely to be breadwinners, and account for a greater percentage of family income (Glynn, 2016). Collier's (2019) findings support the assertion for female borrowers, but the collected sample characteristics for persons of color were a limiting factor of the study. Moreover, some assume that married couples may enroll in IDR to take advantage of loopholes existing in prior IDR programs that consider only individual income and not the household (see Delisle, 2013). Married couples were less likely enrolled in IDR, which may be due to a higher monthly federal repayment $(+\$ 200)$ or to the financial comfort a couple may experience (Collier, 2019).

Research to date provides better information on financial outcomes for those with student debt than for those enrolled in IDR. More widely, researchers have identified that higher student loan debt loads correlate with lower savings (Grinstein-Weiss, et al., 2015), retirement (Elliot et al., 2013), and rates of homeownership for younger adults (Houle \& Berger, 2015). Few researchers have examined the post-college financial situations of those in IDR or conducted comparisons between borrowers in traditionally-based repayment and IDR. The emergent 
research illustrates that when controlling for loan debt, wages, and demographic variables, being enrolled in IDR was only significantly correlated with binary participation in savings and not tied to homeownership or participation in retirement (Collier, 2019).

Policy changes as IDR enrollment continues to gain in popularity must be based on a better understanding of the factors correlated with enrollment and the financial outcomes of enrolling in IDR. Researchers highlighting the outliers enrolled in IDR (see Delisle, 2013) lead to a limited understanding of the usual borrower in IDR. Therefore, sweeping changes to IDR based on these outliers may produce profoundly negative effects to those who may need the financial safety IDR intends to provide.

\section{New Evidence - Findings}

Using a nationally representative sample, this study helps illuminate our baseline understandings of IDR. The complex structure of the SCF (see Federal Reserve, N.D.) requires accounting for both survey weights and multiple imputation. We make use of the SCFCOMBO package (Pence, 2015; for use, see Nielson, 2015) to produce both correct point estimates and correct standard errors to guide inferences. See Appendix Table A1 for descriptive statistics for the analytic sample and notes on how loan debt and wages were calculated.

Testing Demographic Characteristics Prior Research Identified as IDR Predictors.

We conducted regression analyses based on the characteristics that prior literature indicates should predict IDR participation. We analyzed permutations of continuous and categorical approaches to measuring the theoretically-central variables of student loan debt (SLD) and income. Unexpectedly, Table 1 shows that in a nationally representative sample, enrollment in IDR does not seem to be the result of a rational choice that can be predicted by SLD load or income measures. Two exceptions are those earning $<\$ 12,500(B=-.23)$ or when developing a 
debt-to-income ratio $(B=-.00)$. Examining descriptive statistics in Table A1 emphasizes that even though $18 \%$ of respondents have wages $<\$ 12,500$, only $6 \%$ of IDR participants have wages under $\$ 12,500$. We also find level of education does not significantly link to IDR enrollment. These findings complicate an understanding of who enrolls in IDR as nationally representative data reveal no clear, significant trends based on the two measures that prior studies suggest are most central (e.g. Blagg, 2018; Collier, 2019; Frotman \& Gibbs, 2017).

Women, married borrowers, and racial minorities are more likely to enroll in IDR, across most models in Table 1. Our findings support narratives that IDR seems to be an important social safety net for female borrowers (Collier, 2019; Miller, 2017). With emergent research illustrating elevated debt loans of minority borrowers (Scott-Clayton \& Li, 2016) and well-established systematic disadvantages these groups have long faced in the US, the link between these individuals and enrollment in IDR is worth further investigation. Interaction terms illustrate that married women of color are more likely to enroll in IDR across a variety of models $(B=.60-.67$, see Appendix Table A2), but that pattern is itself dependent on yet other interaction terms.

IDR Enrollment, Some College, and High Debt. We conducted a second set of analyses in which we included some variables whose importance was confirmed in exploratory analyses (e.g. Some College) and many interaction terms assessed in sequence. We also took guidance from Looney \& Yannelis' (2018) study and generated a high debt variable consisting of over $\$ 50 \mathrm{~K}$ in student loans. Model 1 introduces the new terms. Based on the importance of interaction terms (observed in Table A2 and elsewhere) we introduced interactions with high debt in Model 2 and with some college in Model 3. In Model 4, we trim back to a more parsimonious model emphasizing the cross-model importance of women in understanding IDR participation: we retain the new education and debt terms, and their interactions with female. 
Table 2 shows that high debt reliably, positively correlates to IDR enrollment ( $B=.10$ to $.30)$ as do both $\log$ income $(B=.02)$ and the educational attainment level of some college (associates degree or some semesters at a 4-year school). These results also show females are more likely to enroll in IDR ( $B=.09$ to .13$)$, but interactions between being female and high debt reliably are negative ( $B=-.13$ to -.30$)$. With the introduction of the high debt and some college measures, minority status is not a reliable predictor of IDR enrollment in Table 2 (as it was in Table 1). Different results in Tables 1 and 2 illustrate the overall complexity of IDR enrollment and emphasize that the approach researchers take may produce different findings.

Financial Outcomes. Enrollment in IDR was not significantly correlated with any of the financial outcomes we examined - see Table 3. One possibility for these findings is that in the absence of IDR, high-debt individuals would show worse financial outcomes, and these statistically insignificant findings are because IDR is in fact equalizing financial outcomes. However, our initial explorations of this possibility were unable to confirm it.

\section{Policy Implications, Alternatives, and Recommendations}

To our knowledge, this brief is one of the first to apply OLS regression to the nationallyrepresentative SCF database as part of an examination of IDR enrollment. However, the models for IDR enrollment have quite low explanatory power, suggesting that either enrollment in IDR is more chance than we previously imagined, or that additional variables not included in our regressions (or this public dataset) could add more explanatory power, such as residency urbanicity (see Collier, 2019). Although the decision to enroll in IDR is also driven by factors not measured in SCF, our models illustrate that borrowers over $\$ 50 \mathrm{~K}$ in loan debt, female borrowers, and perhaps minority borrowers and those with "some" college are linked with increased enrollment. As we are unable to reliably predict who enrolls in IDR based upon 
finances, as prior research would lead us to believe, generating policy from the current understanding seems premature and at risk of being ineffective.

Although our study may not bring much clarity pertaining to loan debt, wages, and IDR enrollment, our null findings themselves bring value to the conversation. First, we do not find that high-earning borrowers are driving IDR enrollment, a finding that stands opposed to prior narratives (Delisle, 2013). Next, our findings are somewhat suggestive that IDR may be helping enrollees remain statistically similar to those in traditional-based repayment regarding homeownership and multiple types of savings.

Due to our conflicting research findings concerning IDR enrollment, we urge policymakers to postpone IDR modifications until after the 2019 release of updated SCF data. The 2019 data will reveal any changes in IDR enrollment since 2016, as the REPAYE plan will be included. As Senators Enzi and Alexander (2018) continue to call for modifications, a policy window may currently exist for IDR reforms despite a lack of clarity on the demographics of IDR participation. Our findings suggest changes to IDR should consider the impacts for women (and maybe minority) borrowers who are more likely than other groups to use IDR. Given the breadwinner status many women (especially women of color) hold, changes in IDR could severely impact families' financial security (Glynn, 2016). Also, given the negative correlation between IDR enrollment and the lowest earners, targeting IDR reforms to the borrowers who could most benefit seems a practical strategy. Potentially, automatic IDR enrollment for lowest earners may be a beneficial strategy. However, without better understanding who the average enrollee is and how IDR participation relates to financial outcomes, modifying IDR could have unintended consequences. In this respect, current information does not provide policymakers a clearer picture of who may be (dis)advantaged by IDR modification. 


\section{References}

Becker, A. (2017). Women hold majority of college degrees and debt-and take longer to pay it off. The American Association of University Women. Retrieved from https://www.aauw.org/research/deeper-in-debt/

Blagg, K. (2018). Who uses income-drive student loan repayment? Urban Institute. Retrieved from https://www.urban.org/urban-wire/who-uses-income-driven-student-loan-repayment

Brooks, J.R. (2018). The case for more debt: Expanding college affordability by expanding income-driven repayment. Utah Law Review (Forthcoming). Retrieved from https://papers.ssrn.com/sol3/Delivery.cfm/SSRN_ID3171724_code238438.pdf?abstractid $=3171724 \&$ mirid $=1$

Collier, D.A. (2019). Understanding IDR: A comparison of financial situations and behaviors between those in traditional student loan repayment and those in income driven repayment. Presented at the Association for Education Financial and Policy (AEFP) national conference 2019, Kansas City, MO.

Delisle, J. (2013). Beware savvy borrowers using income-based repayment. New America. https://www.newamerica.org/education-policy/edcentral/beware-savvy-borrowers-usingincome-based-repayment/

Elliott, W., Grinstein-Weiss, M., \& Nam, I. (2013). Student debt and declining retirement savings. Washington University in St. Louis. Retrieved from https://csd.wustl.edu/publications/documents/wp13-34.pdf

Enzi, M.B., \& Alexander, L. (2018, July 11). CBO letter IDR and forgiveness. https://www.budget.senate.gov/imo/media/doc/CBO\%20letter\%20IDR\%20and\%20Forgi veness.pdf

Friedman, M. (1955). The role of government in public education. In Robert A. Solo (Ed.) Economics and the Public Interest. New Brunswick, NJ: Rutgers University Press.

Frotman, S., \& Gibbs, C. (2017). Too many student loan borrowers struggling, not enough benefiting from affordable repayment options. Consumer Financial Protection Bureau. Retrieved from https://www.consumerfinance.gov/about-us/blog/too-many-student-loanborrowers-struggling-not-enough-benefiting-affordable-repayment-options/

Glynn, S.J. (2016). Breadwinning mothers are increasingly the U.S. norm. Center for American Progress. Retrieved from https://www.americanprogress.org/issues/women/reports/2016/12/19/295203/breadwinni ng-mothers-are-increasingly-the-u-s-norm/ 
Grinstein-Weiss, M., Oliphant, J., Russell, B.D., \& Boshara, R. (2015). Does unsecured debt decrease savings? Evidence from the refund to saving initiative. Washington University in St. Louis. Retrieved from https://csd.wustl.edu/Publications/Documents/RB15-16.pdf

Hillman, N. \& Bruecker, E. (2019). Finding and using student loan data. State Higher Education Executive Officers. Retrieved from https://postsecondarydata.sheeo.org/finding-andusing-student-loan-data/

Houle, J.N., \& Berger, L. (2015). Is student loan debt discouraging homeownership among young adults? Social Service Review, 89(4), 589-621. doi:10.1086/684587

Lachenbruch, P.A. (2010). Stata tip 89: Estimating means and percentiles following multiple imputation. The Stata Journal, 10(3), 469-499.

Looney, A., \& Yannelis, C. (2018). Borrowers with large balances: Rising student debt and failing repayment rates. Brookings Institute. Retrieved from https://www.brookings.edu/wpcontent/uploads/2018/02/es_20180216_looneylargebalances.pdf

Miller, K. (2017). Student debt through the gender lens. Outlook (Summer). Retrieved from https://www.aauw.org/2017/09/01/student-debt-through-the-gender-lens/

Nielsen, R. B. (2015). SCF complex sample specification for Stata. Technical note. Department of Financial Planning Housing and Consumer Economics, University of Georgia, Athens, GA. doi: 10.13140/RG.2.1.4126.8240

Pence, K. (2015). SCFCOMBO: Stata module to estimate errors using the Survey of Consumer Finances. Retrieved from https://econpapers.repec.org/software/bocbocode/s458017.htm

Scott-Clayton, J. \& Li, J. (2016). Black-white disparity in student loan debt more than triples after graduation. Brookings. Retrieved from https://www.brookings.edu/research/blackwhite-disparity-in-student-loan-debt-more-than-triples-after-graduation/

Shireman, R. (2017). Learn now, pay later: A history of income-contingent student loans in the United States. The Annals of the American Academy, 671, 184-201. doi:10.1177/0002716217701673

U.S. Federal Reserve Board. (N.D.). Survey of consumer finances (SCF). Washington, DC. Retrieved from https://www.federalreserve.gov/econres/scfindex.htm

U.S. Government Accountability Office. (2016). Federal student loans: Education needs to improve its income driven repayment plan budget estimates (GAO-17-22). Retrieved from https://www.gao.gov/assets/690/681064.pdf 
Table 1. Enrollment in IDR, Theory-Driven Analyses (Linear Probability Models)

\begin{tabular}{|c|c|c|c|c|c|}
\hline & (1) & (2) & (3) & (4) & (5) \\
\hline \multicolumn{6}{|l|}{ Demographics } \\
\hline Female & $0.07^{*}$ & $0.07^{*}$ & $0.08^{*}$ & $0.08^{*}$ & $0.07^{*}$ \\
\hline Age (centered) & -0.00 & -0.00 & -0.00 & -0.00 & -0.00 \\
\hline Racial Minority & $0.05^{*}$ & $0.05^{*}$ & $0.05^{*}$ & $0.05^{* *}$ & $0.05^{*}$ \\
\hline No children & 0.02 & 0.02 & 0.01 & 0.02 & 0.01 \\
\hline Not married or cohabiting & -0.02 & -0.03 & $-0.08^{*}$ & $-0.09^{* *}$ & $-0.07^{*}$ \\
\hline \multicolumn{6}{|l|}{ Loan Characteristics } \\
\hline SLD (centered) & & 0.00 & 0.00 & & \\
\hline Has private debt & -0.03 & -0.03 & -0.03 & -0.03 & -0.04 \\
\hline \multicolumn{6}{|l|}{ Loan Amount } \\
\hline$\$ 20 \mathrm{~K}-40 \mathrm{~K}$ & -0.04 & & & & -0.02 \\
\hline$\$ 40 \mathrm{~K}-60 \mathrm{~K}$ & -0.01 & & & & 0.00 \\
\hline$\$ 60 \mathrm{~K}-75 \mathrm{~K}$ & 0.05 & & & & $0.07^{+}$ \\
\hline$\$ 75 \mathrm{~K}-100 \mathrm{~K}$ & 0.06 & & & & 0.06 \\
\hline$\$ 100,000+$ & 0.05 & & & & 0.07 \\
\hline \multicolumn{6}{|l|}{ Education } \\
\hline Less than HS Degree & 0.01 & 0.01 & 0.00 & -0.01 & 0.01 \\
\hline Some College & 0.02 & 0.03 & 0.01 & 0.00 & 0.01 \\
\hline Associates Degree & 0.05 & 0.04 & 0.03 & 0.03 & 0.04 \\
\hline Masters & 0.02 & 0.04 & 0.03 & 0.04 & 0.01 \\
\hline Professional Degree or $\mathrm{PhD}$ & 0.07 & 0.10 & 0.11 & $0.12^{+}$ & 0.08 \\
\hline \multicolumn{6}{|l|}{ Income } \\
\hline Wage Income & & & 0.00 & & 0.00 \\
\hline Income Squared & & & -0.00 & & -0.00 \\
\hline \multicolumn{6}{|l|}{ Wage income categories } \\
\hline$<\$ 12,500$ & $-0.23^{* * *}$ & $-0.23^{* * *}$ & & & \\
\hline$\$ 12,500-24,999$ & -0.02 & -0.02 & & & \\
\hline$\$ 25,000-39,999$ & 0.01 & 0.01 & & & \\
\hline$\$ 55,000-74,999$ & 0.03 & 0.03 & & & \\
\hline$\$ 75,000-99,999$ & 0.03 & 0.03 & & & \\
\hline$\$ 100,000+$ & -0.08 & -0.08 & & & \\
\hline Debt to Income Ratio & & & & $-0.00^{* *}$ & \\
\hline$N$ & 1,022 & 1,022 & 1,022 & 1,022 & 1,022 \\
\hline Adjusted $R^{2}$ & 0.03 & 0.03 & 0.00 & 0.00 & 0.00 \\
\hline
\end{tabular}

${ }^{+} p<0.10,{ }^{*} p<0.05,{ }^{* *} p<0.01,{ }^{* * *} p<0.001$

Note: Data from public-use 2016 SCF file. The SCF is a self-reported survey and is subject to respondents incorrectly estimating salary and income. Reference category for education is a four-year degree. Reference category for wage income is $\$ 40,000-\$ 54,999$. 
Table 2. Enrollment in IDR, Exploratory Analyses (Linear Probability Models with Interaction Terms)

\begin{tabular}{|c|c|c|c|c|}
\hline & $\begin{array}{l}(1) \\
\text { Alternative Debt and } \\
\text { Education Coding }\end{array}$ & $\begin{array}{c}(2) \\
\text { Interactions with } \\
\text { High Debt }\end{array}$ & $\begin{array}{c}\text { (3) } \\
\text { Adding Interaction } \\
\text { with Some College }\end{array}$ & $\begin{array}{c}(4) \\
\text { Promising } \\
\text { Model } \\
\end{array}$ \\
\hline \multicolumn{5}{|l|}{ Demographics } \\
\hline Female & 0.03 & $0.09^{+}$ & $0.13^{*}$ & $0.09^{*}$ \\
\hline Racial Minority & 0.02 & 0.06 & -0.02 & 0.02 \\
\hline Married & -0.02 & -0.00 & -0.00 & -0.02 \\
\hline \multicolumn{5}{|l|}{ Interaction Terms } \\
\hline Minority X Female & 0.00 & -0.04 & 0.01 & 0.00 \\
\hline Married X Female & 0.08 & 0.17 & 0.13 & 0.06 \\
\hline Minority X Married & 0.02 & 0.03 & 0.10 & 0.02 \\
\hline F X Min. X Married & 0.33 & 0.33 & 0.31 & 0.36 \\
\hline \multicolumn{5}{|l|}{ Income and Debt Measures } \\
\hline Log Income & $0.02^{* * *}$ & $0.02^{* * *}$ & $0.02^{* * *}$ & $0.02^{* * *}$ \\
\hline Debt to Income Ratio & 0.00 & 0.00 & 0.00 & 0.00 \\
\hline $\mathrm{SLD}<\$ 30 \mathrm{~K}$ & 0.04 & 0.03 & 0.04 & 0.04 \\
\hline $\mathrm{SLD}>\$ 50 \mathrm{~K}$ & $0.10^{* *}$ & $0.30^{* *}$ & $0.30^{* *}$ & $0.14^{* * *}$ \\
\hline Private SLD & -0.03 & -0.03 & -0.03 & -0.03 \\
\hline \multicolumn{5}{|l|}{ Educational Attainment } \\
\hline No College & 0.03 & 0.02 & 0.02 & 0.03 \\
\hline Some College & $0.05^{+}$ & $0.05^{+}$ & 0.04 & $0.10^{* *}$ \\
\hline Advanced Degree & 0.02 & 0.02 & 0.03 & 0.03 \\
\hline \multicolumn{5}{|l|}{ Exploratory Interactions } \\
\hline F High debt & & $-0.27^{*}$ & $-0.30^{*}$ & $-0.13^{*}$ \\
\hline Min High debt & & -0.18 & -0.16 & \\
\hline Marr High debt & & -0.14 & -0.13 & \\
\hline F x Min High debt & & 0.20 & 0.20 & \\
\hline F x Marr High debt & & -0.38 & -0.35 & \\
\hline Min x Marr High debt & & 0.03 & 0.01 & \\
\hline FRM High debt & & 0.25 & 0.13 & \\
\hline F Some College & & & -0.15 & $-0.16^{* *}$ \\
\hline Min Some College & & & $0.26^{+}$ & \\
\hline Marr Some College & & & 0.02 & \\
\hline F x Min Some College & & & -0.16 & \\
\hline F x Marr Some College & & & -0.39 & \\
\hline Min x Marr Some College & & & -0.22 & \\
\hline FRM Some College & & & -0.25 & \\
\hline Some College x High Debt & & & 0.02 & \\
\hline FRM x Some College $\mathrm{x}$ & & & $1.28^{*}$ & \\
\hline \multicolumn{5}{|l|}{ High Debt } \\
\hline$N$ & 1,022 & 1,022 & 1,022 & 1,022 \\
\hline $\operatorname{Adj} R^{2}$ & 0.03 & 0.03 & 0.03 & 0.03 \\
\hline
\end{tabular}

${ }^{+} p<0.10,{ }^{*} p<0.05,{ }^{* *} p<0.01,{ }^{* * *} p<0.001$

Note. $\mathrm{F}=$ Female, Min. $=$ Minority, Marr $=$ Married, $\mathrm{FRM}=$ Female, Racial minority, Married 
Table 3. Financial Outcomes: Savings, Homeownership, and Retirement

\begin{tabular}{|c|c|c|c|c|c|c|c|}
\hline & $\begin{array}{c}(1) \\
\text { Have } \\
\text { Savings, } \\
(\mathrm{Y} / \mathrm{N})^{\mathrm{a}} \\
\end{array}$ & $\begin{array}{c}\text { (2) } \\
\text { Savings } \\
\text { Amount }^{b}\end{array}$ & $\begin{array}{c}\text { (3) } \\
\text { Checking } \\
\text { Amount }\end{array}$ & $\begin{array}{c}(4) \\
\text { Home } \\
\text { Owner }\end{array}$ & $\begin{array}{c}(6) \\
\text { Payday } \\
\text { Loan Use }\end{array}$ & $\begin{array}{l}(7) \\
\text { Saving for } \\
\text { retirement } \\
(\mathrm{Y} / \mathrm{N})^{\mathrm{f}}\end{array}$ & $\begin{array}{c}(8) \\
\text { Retirement } \\
\text { Savings } \\
\text { Amount } \\
\end{array}$ \\
\hline \multicolumn{8}{|l|}{ Student Loan Characteristics } \\
\hline In IDR & -0.01 & 250 & 454 & -0.04 & 0.01 & 0.01 & $-5,960$ \\
\hline SLD (centered) & -0.00 & -0.01 & $0.01-0$ & -0.00 & -0.00 & 0.00 & 0.01 \\
\hline Has private debt & -0.05 & 2,862 & 437 & 0.01 & 0.02 & -0.00 & $-3,076$ \\
\hline \multicolumn{8}{|l|}{ Demographics } \\
\hline Female & 0.04 & $-2,217$ & $-541^{+}$ & $0.06^{*}$ & 0.01 & $-0.11^{* *}$ & -2819 \\
\hline Age (centered) & $-0.00^{* * *}$ & $199^{*}$ & $77^{*}$ & $0.01^{* * *}$ & 0.00 & $0.01^{* * *}$ & $1531^{* *}$ \\
\hline Racial Minority & -0.01 & $-1,148$ & $-807^{+}$ & $-0.11^{* * *}$ & $0.04^{* * *}$ & $-0.14^{* * *}$ & $-16862^{* * *}$ \\
\hline Not married or cohabiting & $-0.07^{+}$ & 2,200 & -403 & $-0.19^{* * *}$ & $0.03^{+}$ & 0.03 & -781 \\
\hline No children & 0.03 & 1,663 & 926 & $-0.05^{*}$ & -0.01 & $0.05^{*}$ & 15,757 \\
\hline \multicolumn{8}{|l|}{ Education, Reference is $B A$} \\
\hline Less than HS Degree & $-0.13^{* * *}$ & 1,849 & $-2,497^{* *}$ & -0.01 & $0.02^{+}$ & $-0.08^{+}$ & $-11,730^{+}$ \\
\hline Some College & -0.04 & $-2,412^{*}$ & $-2,277^{* * *}$ & $-0.08^{* *}$ & $0.06^{* * *}$ & $-0.10^{* *}$ & $-8,878$ \\
\hline Associates Degree & $-0.07^{+}$ & $-2,166^{+}$ & $-2,642^{* * *}$ & 0.01 & $0.06^{* * *}$ & $-0.08^{*}$ & $-17,236^{* *}$ \\
\hline Masters & 0.02 & 2,001 & $-1,546$ & 0.04 & 0.00 & $0.10^{* *}$ & 11,476 \\
\hline Professional Degree or $\mathrm{PhD}$ & -0.04 & 5,023 & 355 & -0.06 & 0.01 & 0.04 & -924 \\
\hline \multicolumn{8}{|l|}{ Wage Income Measures } \\
\hline Wage Income & $0.00^{* * *}$ & $0.10^{*}$ & $0.06^{* * *}$ & $0.00^{* * *}$ & 0.00 & $0.00^{* * *}$ & $0.33^{*}$ \\
\hline Income Squared & $-0.00^{+}$ & 0.00 & -0.00 & $-0.00^{+}$ & -0.00 & $-0.00^{*}$ & -0.00 \\
\hline$N$ & 1,022 & 562 & 1,022 & 1,022 & 1,022 & 389 & 1,022 \\
\hline $\operatorname{Adj} R^{2}$ & 0.03 & 0.12 & 0.07 & 0.28 & 0.02 & 0.15 & 0.06 \\
\hline
\end{tabular}

${ }^{+} p<0.10,{ }^{*} p<0.05,{ }^{* *} p<0.01,{ }^{* * *} p<0.001$

Note: Data from public-use 2016 SCF file. To improve readability, coefficients over 1 in columns 2, 3, and 8 were rounded.

$a$. Have Savings was coded as 1 if our calculation of Savings Amount $>0$; Saving for Retirement was coded as 1 if our calculation of Retirement Savings $>0$.

b. Savings was tabulated by summing X3730, X3736, X3742, X3748, X3754, X3760

c. Checking: sum of (X3506 if X3507=5) (X3510 if X3511=5) (X3514 if X3515=5) (X3518 if X3519=5) (X3522 if X3523=5) (X3526 if X3527=5)

$d$. Home Ownership was set equal to one if the respondent indicated a positive resale value for property they owned (X604, X614, X623, X716, X513, X526)

e. Payday loan use is via a question specific to that topic: $\mathrm{X} 7063$.

$f$. Whether the respondent saves for retirement is based on values of 22 for X3006, X3007, X7513, X7514, X7515, X6848

g. Retirement savings amount calculated as a sum of X6551, X6559, X6552, X6560, X6553, X6561, X6554, X6562, X6756, X6757 
Appendix Table A1. Sample Descriptive Table

\begin{tabular}{|c|c|c|c|}
\hline & $\begin{array}{l}\text { Respondents } \\
\text { in } \mathrm{IDR}^{\mathrm{a}}\end{array}$ & $\begin{array}{c}\text { Respondents } \\
\text { in Traditional } \\
\text { Repayment }\end{array}$ & $\begin{array}{c}\text { All } \\
\text { Respondents } \\
\text { with Debt }\end{array}$ \\
\hline \multicolumn{4}{|l|}{ Demographics } \\
\hline Female & $29 \%$ & $29 \%$ & $29 \%$ \\
\hline Age & 37.7 & 38.0 & 36.9 \\
\hline Racial Minority & $46 \%$ & $40 \%$ & $42 \%$ \\
\hline No children & $46 \%$ & $47 \%$ & $47 \%$ \\
\hline Not married or cohabiting & $40 \%$ & $42 \%$ & $41 \%$ \\
\hline Wage Income & $\$ 62,303$ & $\$ 62,376$ & $\$ 62,356$ \\
\hline \multicolumn{4}{|l|}{ Loan Characteristics } \\
\hline SLD & $\$ 43,106$ & $\$ 39,206$ & $\$ 40,233$ \\
\hline Has private debt & $15 \%$ & $17 \%$ & $16 \%$ \\
\hline In IDR & $100 \%$ & $0 \%$ & $27 \%$ \\
\hline \multicolumn{4}{|l|}{ Educational Attainment } \\
\hline Less than HS Degree & $18 \%$ & $19 \%$ & $19 \%$ \\
\hline Some College & $19 \%$ & $19 \%$ & $19 \%$ \\
\hline Associates & $19 \%$ & $18 \%$ & $18 \%$ \\
\hline Bachelors & $26 \%$ & $28 \%$ & $27 \%$ \\
\hline Masters & $14 \%$ & $13 \%$ & $13 \%$ \\
\hline Professional Degree or $\mathrm{PhD}$ & $5 \%$ & $3 \%$ & $4 \%$ \\
\hline \multicolumn{4}{|l|}{ Financial Outcome Measures } \\
\hline Has Savings & $56 \%$ & $56 \%$ & $56 \%$ \\
\hline $\begin{array}{l}\text { Average amount in savings } \\
\text { (among those with any) }\end{array}$ & $\$ 4,599$ & $\$ 4,614$ & $\$ 4,610$ \\
\hline Average amount in checking & $\$ 4,194$ & $\$ 3,697$ & $\$ 3,832$ \\
\hline Home Ownership & $45 \%$ & $48 \%$ & $48 \%$ \\
\hline Uses payday loans & $6 \%$ & $5 \%$ & $5 \%$ \\
\hline Saves for retirement & $38 \%$ & $38 \%$ & $38 \%$ \\
\hline Amount saved for retirement & $\$ 7,883$ & $\$ 9,940$ & $\$ 9,387$ \\
\hline \multicolumn{4}{|l|}{ Categorical Measures } \\
\hline \multicolumn{4}{|l|}{ Loan Amount } \\
\hline Under $\$ 20 \mathrm{~K}$ & $37 \%$ & $39 \%$ & $38 \%$ \\
\hline$\$ 20 \mathrm{~K}-40 \mathrm{~K}$ & $25 \%$ & $29 \%$ & $28 \%$ \\
\hline$\$ 40 \mathrm{~K}-60 \mathrm{~K}$ & $12 \%$ & $12 \%$ & $12 \%$ \\
\hline$\$ 60 \mathrm{~K}-75 \mathrm{~K}$ & $9 \%$ & $7 \%$ & $8 \%$ \\
\hline$\$ 75 \mathrm{~K}-100 \mathrm{~K}$ & $7 \%$ & $5 \%$ & $6 \%$ \\
\hline$\$ 100,000+$ & $11 \%$ & $8 \%$ & $9 \%$ \\
\hline Loan Less than $\$ 30 \mathrm{~K}$ & $51 \%$ & $55 \%$ & $54 \%$ \\
\hline Loan Over $\$ 50 \mathrm{~K}$ & $33 \%$ & $24 \%$ & $26 \%$ \\
\hline \multicolumn{4}{|l|}{ Wage income: } \\
\hline$<\$ 12,500$ & $6 \%$ & $22 \%$ & $17 \%$ \\
\hline$\$ 12,500-24,999$ & $9 \%$ & $7 \%$ & $8 \%$ \\
\hline$\$ 25,000-39,999$ & $20 \%$ & $15 \%$ & $17 \%$ \\
\hline$\$ 40,000-54,999$ & $16 \%$ & $12 \%$ & $13 \%$ \\
\hline$\$ 55,000-74,999$ & $16 \%$ & $12 \%$ & $13 \%$ \\
\hline$\$ 75,000-99,999$ & $16 \%$ & $12 \%$ & $13 \%$ \\
\hline$\$ 100,000+$ & $15 \%$ & $19 \%$ & $18 \%$ \\
\hline$N$ & 276 & 746 & 1,022 \\
\hline
\end{tabular}


Note The 2016 SCF allows respondents to report up to 6 student loans. Like Blagg (2018), student loan debt was summed across loans $(X 7805, X 7828, X 7851, X 7928, X 7951)$ that respondents reported were self or spousal debt (variables X7978, X7883, X7888, X7893, X7898, X7993). Blagg's report only tabulated federal debt, we aligned with Collier's (2019) design and tabulated total student loan debt which significantly correlated with enrollment in IDR. Total student loan debt was generated using variables X7805, X7828, X7851, X7905, X7928, X7951.

Enrollment in Income driven repayment was determined via variables X9306-X9311. Realigned with Blagg (2018), wage data was tabulate from reported household wages and salary only (X5702).

${ }^{a}$ Means (after imputation) for sub-samples calculated via regression with no covariates; see Lachenbruch (2010) 


\section{Appendix Table A2.}

Showing "Female X Married X Racial Minority" Interaction Term is Significant, But Contingent on "Has Children" Interaction Terms

\begin{tabular}{|c|c|c|c|c|c|c|c|c|}
\hline & $(1)$ & $(2)$ & (3) & $(4)$ & $(5)$ & $(6)$ & $(7)$ & $(8)$ \\
\hline \multicolumn{9}{|l|}{ Demographics } \\
\hline Female & 0.02 & 0.02 & 0.01 & 0.01 & 0.01 & 0.01 & 0.02 & 0.03 \\
\hline Racial Minority & -0.00 & 0.01 & 0.01 & 0.01 & 0.01 & 0.00 & 0.03 & 0.04 \\
\hline Married & 0.05 & 0.04 & 0.01 & -0.00 & -0.00 & 0.04 & 0.04 & 0.01 \\
\hline Has Kids & 0.02 & 0.03 & 0.07 & 0.06 & 0.06 & 0.02 & 0.10 & 0.13 \\
\hline \multicolumn{9}{|l|}{ Interaction Terms } \\
\hline Minority X Female & 0.06 & 0.05 & 0.06 & 0.06 & 0.07 & 0.06 & 0.00 & -0.00 \\
\hline Married X Female & -0.28 & $-0.30^{+}$ & $-0.29^{+}$ & -0.28 & -0.28 & -0.28 & 0.12 & 0.07 \\
\hline Minority X Married & 0.06 & 0.06 & 0.04 & 0.04 & 0.05 & 0.06 & 0.03 & 0.04 \\
\hline Female X Kids & 0.02 & 0.02 & 0.01 & 0.02 & 0.01 & 0.02 & -0.07 & -0.07 \\
\hline Minority X Kids & 0.44 & 0.45 & 0.35 & 0.35 & 0.35 & 0.45 & -0.02 & -0.03 \\
\hline Married X Kids & -0.04 & -0.05 & -0.10 & -0.08 & -0.08 & -0.04 & -0.11 & -0.14 \\
\hline F X Min. X Married & $0.62^{* *}$ & $0.64^{* *}$ & $0.67^{* * *}$ & $0.64^{* * *}$ & $0.63^{* *}$ & $0.60^{* *}$ & 0.26 & 0.36 \\
\hline F X Minority X Kids & $-0.51^{+}$ & $-0.51^{+}$ & -0.45 & -0.45 & -0.45 & $-0.52^{+}$ & - & - \\
\hline Minority X Married X Kids & -0.45 & -0.46 & -0.36 & -0.35 & -0.35 & $-0.47^{+}$ & - & - \\
\hline F X Kids X Married & $0.67^{+}$ & $0.68^{+}$ & $0.68^{+}$ & $0.71^{+}$ & $0.74^{+}$ & $0.73^{+}$ & - & - \\
\hline F X Married X Min. X Kids & -0.22 & -0.23 & -0.26 & -0.28 & -0.32 & -0.26 & - & - \\
\hline \multicolumn{9}{|l|}{ Income and Debt Measures } \\
\hline Log SLD & & $0.02^{+}$ & 0.01 & & & & & -0.02 \\
\hline Wage Income & & & & & & -0.00 & -0.00 & \\
\hline Log Wage Income & & & $0.02^{* * *}$ & 0.03 & 0.03 & & & -0.01 \\
\hline SLD $<\$ 30,000$ & & & & 0.03 & 0.03 & 0.02 & 0.02 & \\
\hline High Debt $(>\$ 50,000)$ & & & & $0.11^{* *}$ & $0.11^{* *}$ & $0.10^{* *}$ & $0.10^{* *}$ & \\
\hline Log Inc X Log SLD & & & & -0.00 & -0.00 & & & 0.00 \\
\hline \multicolumn{9}{|l|}{ Educational Attainment } \\
\hline No College & & & & & 0.03 & 0.01 & 0.00 & \\
\hline Some College or Associates & & & & & $0.05^{+}$ & 0.03 & 0.03 & \\
\hline Advanced Degree & & & & & 0.03 & 0.03 & 0.03 & \\
\hline$N$ & 1,022 & 1,022 & 1,022 & 1,022 & 1,022 & 1,022 & 1,022 & 1,022 \\
\hline$A d j R^{2}$ & 0.00 & 0.01 & 0.02 & 0.02 & 0.03 & 0.01 & 0.02 & 0.02 \\
\hline
\end{tabular}

Note: Data from public-use 2016 SCF file. Reference category for educational attainment is four-year degree.

${ }^{+} p<0.10,{ }^{*} p<0.05,{ }^{* *} p<0.01,{ }^{* * *} p<0.001$ 
Table A3. Alternative Approaches to High Levels of Debt

\begin{tabular}{|c|c|c|c|c|c|c|}
\hline DV IDR Enrollment & (1) & (2) & (3) & (4) & (5) & (6) \\
\hline \multicolumn{7}{|l|}{ Demographics } \\
\hline Female & $0.09^{+}$ & $0.09^{+}$ & $0.09^{+}$ & $0.13^{* * *}$ & $0.09^{+}$ & $0.13^{* * *}$ \\
\hline Racial Minority & 0.01 & 0.01 & 0.01 & $0.05^{*}$ & 0.02 & $0.05^{*}$ \\
\hline Married & -0.04 & -0.03 & -0.03 & 0.02 & -0.03 & 0.02 \\
\hline \multicolumn{7}{|l|}{ Debt/Income Chars } \\
\hline Has private debt & -0.04 & -0.04 & -0.04 & -0.04 & -0.03 & -0.03 \\
\hline LogInc2 & $0.03^{* * *}$ & $0.03^{* * *}$ & $0.03^{* * *}$ & $0.03^{* * *}$ & $0.03^{* * *}$ & $0.03^{* * *}$ \\
\hline DebtToInc2 & $0.00^{+}$ & $0.00^{+}$ & $0.00^{+}$ & $0.00^{+}$ & 0.00 & $0.00^{+}$ \\
\hline \multicolumn{7}{|l|}{ SLD Magnitude } \\
\hline SLD_Under_30 & 0.04 & 0.04 & 0.04 & 0.04 & 0.04 & 0.04 \\
\hline $50 \mathrm{To} 80$ & $0.14^{* *}$ & $0.14^{* *}$ & $0.14^{* * *}$ & $0.14^{* * *}$ & & \\
\hline 80 То 90 & -0.02 & -0.03 & -0.02 & -0.03 & & \\
\hline 90To120 & $0.25^{* * *}$ & $0.25^{* * *}$ & $0.25^{* * *}$ & $0.24^{* * *}$ & & \\
\hline 120To140 & 0.00 & 0.00 & 0.00 & -0.01 & & \\
\hline 140To160 & $0.29^{*}$ & $0.29^{*}$ & $0.29^{*}$ & $0.29^{*}$ & & \\
\hline 160To180 & -0.05 & & & & & \\
\hline 180 To200 & $-0.21^{*}$ & & & & & \\
\hline 200To250 & -0.07 & & & & & \\
\hline 250 Tо 300 & 0.16 & & & & & \\
\hline SLD_Over_300 & -0.02 & & & & & \\
\hline Over $160 \mathrm{~K}$ & & -0.06 & $-0.14^{+}$ & $-0.15^{*}$ & -0.05 & $-0.14^{+}$ \\
\hline Bin50To160 & & & & & $0.15^{* * *}$ & $0.15^{* * *}$ \\
\hline \multicolumn{7}{|l|}{ Educational Attainment } \\
\hline Low Ed & 0.02 & 0.02 & 0.02 & 0.02 & 0.02 & 0.03 \\
\hline Some College & $0.10^{* *}$ & $0.10^{* *}$ & $0.10^{* *}$ & $0.10^{* *}$ & $0.10^{* *}$ & $0.10^{* *}$ \\
\hline High Ed & 0.04 & 0.04 & 0.03 & 0.04 & 0.04 & 0.03 \\
\hline \multicolumn{7}{|l|}{ Interaction Terms } \\
\hline Min x Fem & 0.01 & 0.01 & 0.01 & & 0.01 & \\
\hline Marr x Fem & 0.06 & 0.06 & 0.06 & & 0.06 & \\
\hline Min x Marr & 0.04 & 0.04 & 0.03 & & 0.03 & \\
\hline F x Marr x Min & 0.35 & 0.35 & 0.35 & & 0.36 & \\
\hline High x Female & $-0.11^{*}$ & $-0.11^{+}$ & $-0.11^{+}$ & $-0.10^{+}$ & $-0.13^{*}$ & $-0.12^{*}$ \\
\hline F x Some Coll & $-0.16^{* *}$ & $-0.16^{* *}$ & $-0.16^{* *}$ & $-0.17^{* *}$ & $-0.16^{* *}$ & $-0.17^{* *}$ \\
\hline High Ed X 160K Debt & & & 0.11 & 0.12 & & 0.13 \\
\hline$N$ & 1,022 & 1,022 & 1,022 & 1,022 & 1,022 & 1,022 \\
\hline $\operatorname{Adj} R^{2}$ & 0.04 & 0.04 & 0.04 & 0.04 & 0.04 & 0.03 \\
\hline
\end{tabular}

Note: Data from public-use 2016 SCF file

${ }^{+} p<0.10,{ }^{*} p<0.05,{ }^{* *} p<0.01,{ }^{* * *} p<0.001$ 